\title{
LEARNING THROUGH A SETS-BASED MODULE TO IMPROVE STUDENTS' LEARNING OUTCOMES AND CRITICAL THINKING SKILLS
}

\author{
Muhibbuddin $^{1^{*}}$, Risa Rianda ${ }^{2}$, Cut Nurmaliah ${ }^{3}$ \\ ${ }^{1}$ Dr, University of Syiah Kuala, Banda Aceh, Indonesia, muhibbuddin@unsyiah.ac.id \\ 2Universitas Syiah Kuala, Banda Aceh, Indonesia, risarianda.mpbio18@edu.unsyiah.ac.id \\ ${ }^{3}$ Dr, Universitas Syiah Kuala, Banda Aceh, Indonesia, cutnurmaliah@fkip.unsyiah.ac.id \\ ${ }^{*}$ Corresponding Author
}

\begin{abstract}
Good learning outcomes and critical thinking skills are important aspects that students must have. Several studies have shown that students have poor learning outcomes and critical thinking skills. Therefore it is necessary to improve the learning system using learning modules based on Science, Environment, Technology, and Society (SETS). This study aims to determine the effect of implementing the SETS-based Problem Based Learning (PBL) learning model on improving student learning outcomes and critical thinking skills in the Human Excretion System material. This research was conducted using an experimental method with a pretest-posttest control group design. The research subjects consisted of 128 students who were grouped into experimental and control groups where each group consisted of 64 students. The experimental group got SETS based Problem Based Learning (PBL) model, while the control group used a conventional learning model using textbooks. The parameters measured are learning outcomes and critical thinking skills. Data collection was carried out through the pretest and posttest. Improved learning outcomes and critical thinking skills were analyzed using the normalized gain (n-gain) calculation. Two difference test means with an independent test sample t-test were used to test the difference in the improvement of learning outcomes and critical thinking skills between the two groups. The results showed a significant difference in the improvement of learning outcomes and critical thinking skills between the two groups. The application of the SETS-based Problem Based Learning (PBL) learning model has a significant effect on improving student learning outcomes and critical thinking skills on the excretion system material.
\end{abstract}

Keywords: PBL, SETS module, learning outcome, critical thinking

\section{INTRODUCTION}

The learning process is closely related to learning outcomes. Low learning outcomes are related to students' ability to accept and understand the subject matter (Babadoğan et al., 2010; Cavus \& Sharif, 2014). In addition, the implementation of the learning process should not only refer to the delivery of information to students but also refer to thinking skills. One of the most important skills in the learning process is critical thinking (Palennari et al., 2018). Early studies show that the Biology learning process in high school has not maximized critical thinking skills and learning outcomes. This is indicated by the presence of $56.25 \%$ of students who did not meet the minimum completeness criteria $(\mathrm{KKM}=75)$. The ability of students to understand a concept is strongly influenced by the learning process and the ability of teachers to choose and implement learning strategies. One of the efforts that can be made to improve the quality of the learning process is through the use of modules. The use of modules can help students to understand conceptual learning that leads to the optimization of learning outcomes and critical thinking skills (Fauzia et al., 2017; 
Mubarok et al., 2015; Ugras \& Cil, 2012; Zukmadini \& Jumiarni, 2018). Modules are teaching materials that are designed as a whole, systematically, interestingly, and contain learning materials that are planned and designed to help students master specific learning goals (Alias \& Siraj, 2012; Chantaranima \& Yuenyong, 2014; Dumitrescu et al., 2014; Lee \& Osman, 2012). Science Environment, Technology, and Society (SETS) is a module development approach. Previous research has shown the positive effect of using SETS-based modules on learning outcomes (Arlitasari et al., 2013; Azmi, 2018; Muzari et al., 2016; Oktaviani et al., 2017; Tamimiya et al., 2017; Vaino et al., 2015; Wasoso \& Hartono, 2013; Wulandari et al., 2015). These studies were developed in chemistry learning and did not study critical thinking skills. Research on the use of SETSbased modules in biology learning on human excretory system material has never been done before. This research was conducted to determine the effect of implementing the SETS-based Problem Based Learning (PBL) learning model on improving learning outcomes and critical thinking skills of students in the Human Excretion System material.

\section{RESEARCH METHODOLOGY}

This research used experimental methods with group control of pretest and posttest design(Gall et al., 2003). The details of the research design can be seen in Table1.

Table1. Pretest-posttest Control Group Design

\begin{tabular}{|c|c|c|c|c|}
\hline Sample & Classes & Pretest & Treatments & Posttest \\
\hline Random & Experiment & $\mathrm{O}_{1}$ & $\mathrm{P}_{1}$ & $\mathrm{O}_{2}$ \\
\hline Random & Control & $\mathrm{O}_{3}$ & - & $\mathrm{O}_{4}$ \\
\hline
\end{tabular}

Information:

$\mathrm{O}_{1}$ : Pretest before treatment is given to class of experiment

O2: Posttest before treatment is given to class of experiment

O3: Pretest before treatment is given to class of control

O4: Posttest before treatment is given to class of control

$\mathrm{P}_{1}$ : Treatment to class of experiment with PBL \&module based SETS

The research subjects were 128 students who were grouped into experimental and control groups where each group consisted of 64 students who were randomly selected. The experimental group got learning with the Problem Based Learning (PBL) model using SETS-based modules, while the control group used the conventional learning model using textbooks. The parameters measured are learning outcomes and critical thinking skills. The data on the learning outcomes of critical thinking skills were obtained through the pretest and post-test. The test instrument used was 50 multiple-choice objective tests. The research was conducted in January-February 2020 at one of the Senior High Schools in Banda Aceh City, Indonesia.

\section{DATA AND ANALYSIS}

Calculation of normalized gain (n-gain) using the Meltzer formula (2002) is used to determine the increase in learning outcomes and critical thinking skills. Two difference test means with independent test sample ttest were used to test the difference in the improvement of learning outcomes and critical thinking skills between the experimental group and the control group.

\section{FINDINGS AND DISCUSSION}

\subsection{Learning outcome}

The results of measurement and analysis of learning outcomes showed that students' initial knowledge was low in understanding the concept of the excretion system in humans, with the pre-test mean scores of the control group were 43.47 and 44.81 in the experimental group. The pre-test result is lower than the Minimum Completeness Criteria (KKM). The results of the pretest mean difference test between the experimental class and the control class (Table-2) showed no significant difference. The mean of the pretest, posttest, and $\mathrm{N}$-Gain of the experimental and control group students as a whole is presented in Figure-1. 


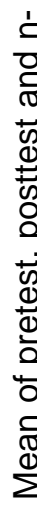

立
81

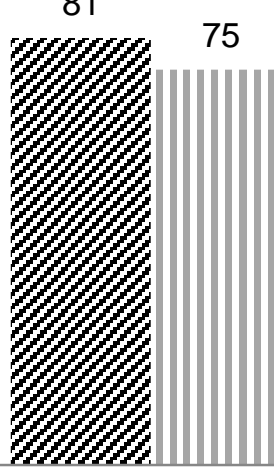

Postest
80,92

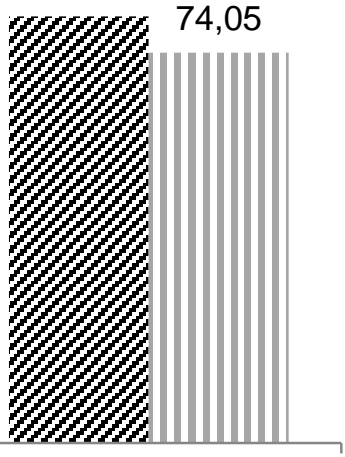

$\mathrm{N}$-Gain

Pretest

च Eksperimen || Kontrol

The results of the pretest and n-gaın mean ditterence test showed a signitıcant ditterence ( I able 2 ). It means that the application of the Problem Based Learning (PBL) learning model using SETS-based modules is effective in improving students' understanding abilities

Table 2. Pretest and n-gain mean difference test

\begin{tabular}{|c|c|c|c|c|c|}
\hline $\begin{array}{l}\text { Learning } \\
\text { outcome }\end{array}$ & Groups & Normality* & Homogeneity** & t-test & Significance \\
\hline \multirow{2}{*}{ Pre-test } & Experiment & $\begin{array}{c}\mathrm{X}_{\text {hit }}^{2}(5,19)<\mathrm{X}_{\text {table }}^{2} \\
(9,48) \text { (Normal) }\end{array}$ & \multirow{2}{*}{$\begin{array}{c}\mathrm{F}_{\text {count }}(1,36)< \\
\mathrm{F}_{\text {table }}(1,52) \\
\text { Homogenous }\end{array}$} & \multirow{2}{*}{$\begin{array}{c}\mathrm{T}_{\text {count }}(0,76)< \\
\mathrm{t}_{\text {table }}(1,97)\end{array}$} & \multirow{2}{*}{$\begin{array}{l}\text { Not } \\
\text { significantly } \\
\text { different }\end{array}$} \\
\hline & Control & $\begin{array}{c}\mathrm{X}_{\text {hit }}^{2}(3,15)<\mathrm{X}_{\text {table }}^{2} \\
(9,48) \text { (Normal) }\end{array}$ & & & \\
\hline \multirow{2}{*}{ n-Gain } & Experiment & $\begin{array}{c}X_{\text {hit }}^{2}(2,90)<X_{\text {table }}^{2} \\
(9,48)(\text { Normal) }\end{array}$ & \multirow{2}{*}{$\begin{array}{c}\mathrm{F}_{\text {count }}(1,09)< \\
\mathrm{F}_{\text {table }}(1,52) \\
\text { Homogeneous }\end{array}$} & \multirow{2}{*}{$\begin{array}{c}\mathrm{T}_{\text {count }}(3,01)> \\
\mathrm{t}_{\text {table }}(1,97)\end{array}$} & \multirow{2}{*}{$\begin{array}{l}\text { Significantly } \\
\text { different }\end{array}$} \\
\hline & Control & $\begin{array}{c}X_{\text {hit }}^{2}(1,56)<X_{\text {table }}^{2} \\
(9,48)(\text { Normal) }\end{array}$ & & & \\
\hline
\end{tabular}

Description:

${ }^{*}$ Chi square test (Normal : $X^{2}{ }_{\text {count }}<X_{\text {table }}^{2} ; \alpha=0,05$ )

${ }^{* *} \mathrm{~F}$ test (Homogeneous : $\mathrm{F}_{\text {count }}<\mathrm{F}_{\text {table }} ; \alpha=0,05$ )

The initial learning outcomes of students in the experimental and control groups were not significantly different (Table-2). This shows that students in both groups have the same abilities. On the other hand, the increase in learning outcomes (n-gain) showed significantly different results (Table-2). Students in the experimental group had higher n-gain than those in the control group (Figure-1). The difference in n-gain between the two groups was caused by the implementation of SETS-based PBL learning. The use of SETSbased modules with the PBL model is proven to create more meaningful and relevant learning so that students can actively participate, are able to analyze and discuss, and solve every problem. Learning also focuses more on applying concepts, theories, and techniques in a contextual manner rather than memorizing. Research conducted by Shofiyah et al., (2013) also revealed that good learning is contextual learning, and learning with the SETS vision will be able to improve student learning outcomes. The learning process of the PBL model in this study pays attention to initial knowledge, examines various phenomena that exist in the surrounding environment (contextual), is student-centered, creates interactive, fun, interesting learning through the use of pictorial modules, the latest information related to material, and links system material excretion with SETS. The use of SETS-based modules with the PBL model also creates an independent learning process for students, this is because the module is equipped with various student worksheets that contain activities related to the human excretion system. One example is students doing lab 
work to test glucose and protein content in urine. These activities allow students to construct the concepts they have learned.

\subsection{Analysis of Critical Thinking Skills}

The results of measurement and analysis of critical thinking skills and students' initial knowledge in understanding the concept of the excretory system in humans are shown in Figure-2.

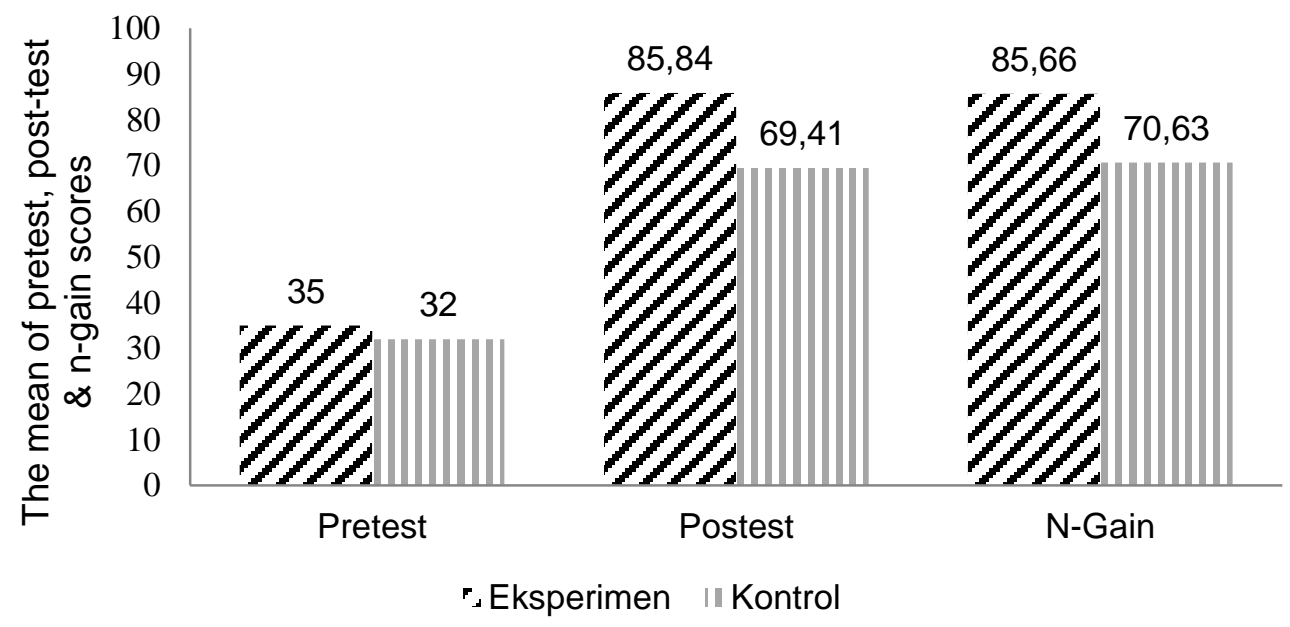

Figure-2. The mean of pretest, post-test and n-gain scores

The initial ability of critical thinking skills in the experimental and control groups did not have a significant difference (Table-3). This shows that the students have the same initial critical thinking skills before being treated to the application of the Problem Based Learning (PBL) learning model using SETS-based modules. Meanwhile, the improvement in critical thinking skills (n-gain) showed a significantly different result (Table-3). This difference is caused by the application of the Problem Based Learning (PBL) learning model using SETS-based modules in the experimental group. The difference between the $\mathrm{n}$-gain of critical thinking skills in the experimental class and the control class is 15.03 .

Learning with PBL using SETS-based modules makes it easier for students to understand the material being taught, improves students 'thinking skills about aspects of science, and increases students' activeness in the learning process (Abualrob \& Shah, 2012; Pedretti \& Bellomo, 2013; Widiyanti et al., 2015). Several previous studies (Amrullah et al., 2017; Sari et al., 2016; Susilogati et al., 2014; Sutikno \& Setyasto, 2019) also revealed that learning with modules will help students learn actively, independently, giving students opportunities to conduct experiments, discussions, and deepen understanding of concepts that can improve student achievement and critical thinking skills.

Table 3. Different tests of the mean of critical thinking skills pretest and $n$-gain scores

\begin{tabular}{|c|c|c|c|c|c|}
\hline $\begin{array}{l}\text { Learning } \\
\text { outcome }\end{array}$ & Groups & normality* & Homogeneity** & t-test & Significance \\
\hline \multirow{2}{*}{ Pre-test } & Experiment & $\begin{array}{c}X_{\text {count }}^{2}(6,57)< \\
X_{\text {table }}^{2}(9,48) \\
(\text { Normal })\end{array}$ & \multirow{2}{*}{$\begin{array}{c}\mathrm{F}_{\text {count }}(1,24)< \\
\mathrm{F}_{\text {table }}(1,52) \\
\text { Homogenous }\end{array}$} & \multirow{2}{*}{$\begin{array}{c}\mathrm{T}_{\text {count }}(1,46)< \\
\mathrm{t}_{\text {table }}(1,97)\end{array}$} & \multirow{2}{*}{$\begin{array}{c}\text { Not } \\
\text { significantly } \\
\text { different }\end{array}$} \\
\hline & Control & $\begin{array}{c}\mathrm{X}_{\text {count }}^{2}(4,05)< \\
\mathrm{X}_{\text {table }}^{2}(9,48) \\
\text { (Normal) }\end{array}$ & & & \\
\hline N-Gain & Experiment & $\begin{array}{c}\mathrm{X}_{\text {count }}^{2}(5,93)< \\
\mathrm{X}_{\text {table }}^{2}(9,48) \\
\text { (Normal) }\end{array}$ & $\begin{array}{c}\mathrm{F}_{\text {count }}(1,31)< \\
\mathrm{F}_{\text {table }}(1,52) \\
\text { Homogenous }\end{array}$ & $\begin{array}{c}\mathrm{T}_{\text {count }}(6,75)> \\
\mathrm{t}_{\text {table }}(1,97)\end{array}$ & $\begin{array}{c}\text { Significantly } \\
\text { different }\end{array}$ \\
\hline
\end{tabular}




\begin{tabular}{|l|c|c|l|l|l|}
\hline & Control & $\begin{array}{c}\mathrm{X}_{\text {count }}(7,20)< \\
\mathrm{X}_{\text {table }}(9,48) \\
\text { (Normal) }\end{array}$ & & & \\
\hline
\end{tabular}

Description:

${ }^{*}$ Chi square test (Normal : $X_{\text {count }}^{2}<X_{\text {table }}^{2} ; \alpha=0,05$ )

${ }^{* *} F$ test (Homogenous : $F_{\text {count }}<F_{\text {table }} ; \alpha=0,05$ )

The research data shows that the implementation of the SETS-based module with the PBL model is able to develop students' critical thinking skills. This is because the SETS-based module allows students to identify problems in the student worksheets in the module. Students' critical thinking skills are also trained through practicum regarding the human excretion system. Students are trained to formulate problems and hypotheses, then prove the hypothesis through practicum and report preparation. The activity of formulating problems and hypotheses from the material of the human excretion system is an activity of critical thinking skills. This activity requires high-level thinking processes, analytical skills, and evaluating each problem. The results of this study indicate that learning with the PBL model using SETS-based modules contributes greatly to the efforts to improve learning outcomes and critical thinking skills of students in the human excretion system material.

\subsection{Conclusion}

The results showed an increase in learning outcomes in the experimental class with an average score of 80.92 while the control class was 74.05. The same thing is shown in the improvement of critical thinking skills in the experimental class with an average score of 85.66 and the control class 70.63 . The t-test results showed a significant difference between the pretest score and the $\mathrm{n}$-gain score at the $95 \%$ significant level $(\alpha=0.05)$. The conclusion is that the application of the Problem Based Learning (PBL) learning model using SETS-based modules has a significant effect on improving learning outcomes and critical thinking skills of students on the excretion system material.

\section{BIBLIOGRAPHY}

Abualrob, M. M. A., \& Shah, M. (2012).Science Technology and Society Modules Development Process and Testing on its Effectiveness.Procedia-Social and Behavioral Sciences, 46:811-816.

Alias, N., \& Siraj, S. (2012). Effectiveness Of Isman Instructional Design Model In Developing Physics Module Based On Learning Style and Appropriate Technology. Procedia-Social and Behavioral Sciences, 64:12-17.

Amrullah, A., Hadisaputo, S., \& Supardi, K. (2017). Pengembangan Modul Chemireligiousa Terintegrasi Pendidikan Karakter Bervisi SETS. Jurnal Inovasi Pendidikan Kimia, 11(1):1872-1883.

Arlitasari, O., Pujayanto, \& Budihartati, R. (2013).Pengembangan Bahan Ajar IPA Terpadu Berbasis SALINGTEMAS dengan Tema Biomassa Sumber Energi Alternatif Terbarukan. Jurnal Pendidikan Fisika, 1(1):81-89.

Azmi, N., T. (2018). Pengembangan Modul Sistem Pertahanan Tubuh Berbasis Science, Technology, Engineering And Mathematics (STEM) Terintegrasi Project Based Learning (PjBL) terhadap Hasil Belajar dan Kemampuan Pemecahan Masalah Siswa. Thesis. Banda Aceh: Universitas Syiah Kuala.

Babadoğan, C., Kutlu, Ö., \& Öğülmüş, S. (2010). Design and Development Of Infinited Blue Project 9th-12 Th Grades Modular Program. Procedia-Social and Behavioral Sciences, 2: 3389-3394.

Cavus, N., \& Sharif, M. (2014). Learning Management Systems Use in Science Education. Procedia-Social and Behavioral Sciences, 143:517-520.

Chantaranima, T., \& Yuenyong, C. (2014). The Outcomes of Teaching and Learning About Sound Based on Science Technology and Society (STS) Approach. Procedia-Social and Behavioral Sciences, 116: 2286-2292.

Dumitrescu, C., Olteanu, R. L., Gorghiu, L. M., \& Gorghiu, G. (2014). Learning Chemistry in the Frame of 
Integrated Science Modules - Romanian Student's Perception. Procedia-Social and Behavioral Sciences, 116: 2516-2520.

Fauzia, F., Susilowati, E., \& Indriyanti, R. (2017). Learning Materials on Environmental Change of Waste and Waste Recycling With SETS Bervisi Module to Improve Student Learning Outcomes in SMA. Journal of Biology Education, 6(3):342-349.

Gall, M.D., Gall, J.P., and Borg, W.R. 2003. Educational Research An Introduction. Boston: Pearson Education Inc.

Lee, T. T., \& Osman, K. (2012). Interactive Multimedia Module in the Learning of Electrochemistry: Effects on Students' Understanding and Motivation. Procedia-Social and Behavioral Sciences, 46: 13231327.

Meltzer, D. E. (2002). The Relationship Between Mathematics Preparation and Conceptual Learning Gains in Physics: A Possible "Hidden Variable" in Diagnostic Pretest Scores. American Journal of Physics, 70(12):1259-1268.

Mubarok, I., Susilowati, E., \& Dewi, K. (2015). Development of Ecosytem Subject Module With SETS-Vision and Islamic Value. International Conference on Mathematics, Science, and Education (ICMSE) 2015, Semarang (March).

Muzari, I., Ashadi, \& Baskoro, P. adi. (2016). Pengembangan Modul IPA Terpadu Berbasis SETS Pada Tema Makanan Sehat dan Tubuhku Untuk Meningkatkan Hasil Belajar. Jurnal Inkuiri, 5(1):21-27.

Oktaviani, P., Hartono, \& Marwoto, P. (2017). Pengembangan Multimedia Interaktif Bervisi SETS sebagai Alat Bantu Model Problem Based Learning (PBL) dalam Pembelajaran IPA di SMP untuk Meningkatkan Kemampuan Berpikir Kritis dan Keterampilan Sosial Peserta Didik. Pancasakti Science Education Journal, 2(2):125-137.

Palennari, M., Lodang, H., \& Faisal. (2018). Pembedayaan Keterampilan Berpikir Kritis Mahasiswa pada Perkuliahan Biologi Dasar Melalui Problem Based Learning. Seminar Nasional Pendidikan Biologi, Makasar (Juni).

Pedretti, E., \& Bellomo, K. (2013). A Time for Change: Advocating for STSE Education Through Professional Learning Communities. Canadian Journal of Science, Mathematics and Technology Education, 13(4):415-437.

Sari, D., Wahyuni, S., \& Supriadi, B. (2016). Pengembangan Modul Pembelajaran IPA Berbasis Salingtemas (Sains, Lingkungan, Teknologi, Masyarakat) Di SMP. Jurnal Pembelajaran Fisika, 5(3):218-225.

Shofiyah, S., Indriyanti, D., \& Binadja, A. (2013). Pengembangan Perangkat Pembelajaran IPA Bervisi SETS Kompetensi Terkait Pengendalian Hama dan Penyakit Organ Tumbuhan. Lembaran IImu Kependidikan, 42(2):107-115.

Susilogati, S., Binadja, A., \& Hidayah, F. (2014). Developing Module of Practical Chemistry Physics SETS Vision Activity to Increase Science Process Skills of Student Teacher. Greener Journal of Educational Research, 4(2):030-035.

Sutikno, P., \& Setyasto, N. (2019). Pengembangan Perangkat Pembelajaran SD dengan Model Problem Based Learning (PBL) Bervisi Science, Environment, Technology, and Society (SETS) Berbantuan MIRACAST. Jurnal Pendidikan (Teori Dan Praktik), 4(1): 18-24.

Tamimiya, K., Gani, A., \& Putra, P. (2017). Pengembangan Modul Pembelajaran IPA Berbasis SETS untuk Meningkatkan Collaborative Problem Solving Skills Siswa SMP pada Pokok Bahasan Cahaya. Jurnal Pembelajaran Fisika, 5(4):392-398.

Ugras, M., \& Cil, E. (2012). Troubles Which Class Teachers In Primary Education Encounter In New Science and Technology Teaching Program. Procedia-Social and Behavioral Sciences, 47:1545-1548.

Vaino, T., Vaino, K., \& Rannikmäe, M. (2015). Enhancing Students' Interests in Science and Technology Related Careers Through a Specially Designed Optional Course. Procedia-Social and Behavioral Sciences, 177:331-335.

Wasoso, S., \& Hartono. (2013). Implementasi Model Problem Based Learning Bervisi SETS untuk Meningkatkan Kemampuan Pemecahan Masalah IPA dan Kebencanaan Oleh Siswa. Journal of Innovative Science Education, 2(1):63-67. 
Widiyanti, F., Indriyanti, D. R., \& Ngabekti, S. (2015). The Effectiveness Of The Application Of Scientific Literacy-Based Natural Science Teaching Set Toward The Students' Learning Activities and Outcomes On The Topic Of The Interaction Of Living Organism And Environment. Jurnal Pendidikan IPA Indonesia, 4(1):20-24.

Wulandari, T. N., Ashadi, \& Yamtinah, S. (2015). Pengembangan Modul Pereaksi Kimia Berbasis SETS Pada Mata Pelajaran Analisis Kimia Dasar Kelas X. Jurnal Inkuiri, 4(4):54-60.

Zukmadini, A. Y., \& Jumiarni, D. (2018). Developing Antimicrobial Medicinal Plants Pocketbook Based On Local Wisdom Of Muko-Muko And Serawai Ethnics. Jurnal Pendidikan Biologi Indonesia (JPBI), 4(2):95-104. 